\title{
DEVELOPMENT OF DESCRIPTIVE TEXT LEARNING E-MODULE WITH A CONSTRUCTIVISTIC APPROACH
}

\author{
Puja Murdianto ${ }^{1)}$, Aunurrahman ${ }^{2)}$, Indri Astuti ${ }^{3)}$ \\ 1) UNTAN, Pontianak, Indonesia \\ E-mail:pujaaja87@student.untan.ac.id \\ 2) UNTAN, Pontianak, Indonesia \\ E-mail: aunurrahman@fkip.untan.ac.id \\ 3) UNTAN, Pontianak, Indonesia \\ E-mail:indribk91@yahoo.com
}

\begin{abstract}
The main objective of this research is to develop learning e-modules in teaching English in the classroom as well as to produce and disseminate learning media. This e-module can be used on smartphones and this e-module uses a constructivist approach. The steps of the research model are defined, designed, developed, and disseminated/implemented. Participants in this study were teachers and students of MAN 3 Pontianak. The data collection technique in this study refers to the interview list guidelines, namely the questionnaire. Data collection tools are learning outcomes and questionnaire sheets. This study uses a qualitative descriptive approach for data analysis. The results showed that the design of the electronic module learning development in this study consisted of an analysis of curriculum and learning materials, an analysis of the characteristics of students and an analysis of student learning outcomes. The steps for developing an electronic module are by submitting a lot of learning materials and then being reviewed by experts according to their backgrounds as media experts and learning materials experts. The results of the expert review showed that the average score of the electronic module was 3.77 (range $1-4$ ) and also the test given to students before applying it. The response of students after using the e-module showed $83.2 \%$ which means a positive response. This e-module can be applied to students because it has criteria such as self-instruction, stand alone, adaptive and user friendly. The learning outcomes of this research are that students are more active and construct themselves in learning descriptive texts in English class. The Minimum Completeness Criteria (KKM) in this study is 75 and the average is 79.04, which means that the use of e-modules in teaching descriptive texts is effective and can increase their scores.
\end{abstract}

Kata Kunci: E-learning modules; descriptive text; approach constructivist

\section{INTRODUCTION}

Learning is an activity carried out with the aim of obtaining competencies in the form of skills and knowledge needed. One of the lessons taught in schools is English. Learning English covers four aspects of knowledge including reading, listening, writing and speaking. In the aspect of reading or reading, there are several types of texts that must be studied, one of which is descriptive text or better known as descriptive text. Descriptive text is one of the sub-materials of learning English in high school related to the students' ability in language, both actively and passively. But in reality, English subjects, especially descriptive text material that is learned in high school tenth grade, is a new sub-learning material, making it difficult for students to understand the topic.
One way that researchers can use to help students solve problems in learning English, especially in descriptive text material is by electronic learning modules (e-modules) or digital books. The advantages of learning using e-modules are that students can learn according to their own pace and learning style, are easily accessible, and are equipped with audio visuals. Learning by using e-modules also provides opportunities for students to repeat the parts of the material that have not been mastered.

According to Daryanto (2013), learning modules are teaching materials that are comprehensively and systematically arranged which contain a set of learning experiences that are planned and designed to help students master specific learning objectives. In line with Daryanto, the Ministry of Education stated that the module is a learning tool that contains materials, methods, limitations, and 
evaluation methods that are designed systematically and attractively to achieve the expected competencies according to the level of complexity. In its presentation, the e-module implements an independent learning system (selfinstruction), which means that learning materials can be studied by students independently with limited assistance from educators, which are packaged in a systematic, interesting and not boring way.

Characteristics and learning styles of students make a learning process need to be designed appropriately, so as to help students understand the concept of the material being studied. According to Keefe (1979) (in Gufron 2014), one approach that can be used to support the learning process oriented towards differences in student learning styles is a constructivist approach. The constructivist approach was pioneered by Piaget, Bruner and Vigotsky who explained that students need to actively construct knowledge. According to Astuti (2020), educators are tasked with designing and creating learning experiences that can help students understand the concepts and knowledge being studied.

Some of the results of research that have been carried out are Sukardi (2015) entitled "Constructivistic Model Building Concepts for seventh grade English Learning at state middle school 4 of Siantan" concluding that the application of constructivism learning in learning English Model through multimedia in teaching learning helps students to gain English skills and practice them in daily life. A similar study was also conducted by Pratama (2019) entitled "Development of a Descriptive Text Material Module for tenth grade English Subjects at high school of Dawarblandong Mojokerto" concluded that the use of the media module was in accordance with the needs and had met the feasibility test and effectiveness test. can increase the acquisition of good learning outcomes.

Based on these problems, this study aims to develop an emodule for learning English with descriptive text material with a constructivist approach to tenth grade students at MAN 3 Pontianak. This research is important to do as a theoretical basis for developing relevant learning media in English lessons.

\section{METHODS}

This research was conducted at MAN 3 Pontianak. The object of research in this research is the e-module "Descriptive Text" with research participants being educators and students of class X MAN 3 Pontianak.

This study uses 4 stages in the development of e-modules which are described in detail as follows:

The Define stage consists of:

Front and analysis (Analysis of curriculum and learning resources). This stage is the initial diagnosis to review the curriculum used in learning. Curriculum analysis is useful for determining which competencies will be developed teaching materials.
Learner analysis (Analysis of student characteristics). Characteristics assessment is carried out by considering academic abilities and learning styles.

Task Analysis. Task analysis is the part where researchers must formulate what tasks must be done by students in order to achieve the expected competencies .

Concept Analysis (Analysis of concepts to be taught). At this stage, the formulation of the concept that will be outlined in the learning e-module is descriptive text in terms of (1) the purpose of the text (2) the general structure of the text, and (3) features of grammar.

Specfying instructional objectives (Formulating learning objectives). This stage is related to the learning objectives so that they do not deviate from the previously formulated competencies. The main purpose of this research is for students to understand the material of descriptive text.

\section{The Design phase consists of:}

Constructing criterion-referenced test. (compiling criteria test). The preparation of the test was carried out as an evaluation tool to determine the achievement of competencies and learning objectives that were expected after the implementation of learning activities (trials) using descriptive text e-modules through constructivist approaches. The test is arranged in the form of 2 discourses with 10 questions in the form of multiple choice

Media selection. In accordance with the main objective in this research is to develop and produce an e-module for learning English with descriptive text material, the selection of the appropriate media is electronic media based on the learning module.

Format selection (wide selection of format). According to Sanaky (2015), the formats used in the preparation of the learning modules in this research are: (1) general instructions, (2) learning materials, (3) worksheets.

\section{The Develop Phase consists of:}

Expert appraisals (Appraisal an expert). The design of the learning e-module has been tested and validated by experts to assess the feasibility of the product design. In this study, product validation will be carried out by five expert lecturers to assess the feasibility of the content and questions contained in the module, and five media expert lecturers to assess the e-module design.

Developmental testing. The learning module trials that have been validated by experts are followed by 3 trials, namely One to One trials, small group trials and main group trials.

\section{Phase Disseminate / Deploy (Dissemination)}

The dissemination stage in this study was carried out at the school where the research took place, namely at MAN 3 Pontianak, as well as in the English Subject Teacher Consultation (MGMP) working group at the MA level throughout Pontianak. 
This study uses two data collection techniques, namely interviews and documentation. In this study the instruments used to collect data were questionnaire sheets, interview guidelines and document recording devices.

Data analysis in this study used qualitative methods . Qualitative data analysis in the use of researchers to describe the findings of the research through the collection of da ta results of the validation module and a nalisis response learners. The analysis used is the interactive analysis model proposed by Miles and Huberman in Sugiono (2014), namely: data collection, data presentation, and drawing conclusions. The qualitative analysis will be carried out in the following stages:

The activities carried out to analyze the results of the validation of the experts are: Recap the assessment of the validation results of material experts and media experts, Create and analyze tables of validation results by experts, and Finding the average of each criterion with the formula according to Khabib ah (2006) in Wicaksono (2014).

$$
K_{i}=\frac{\sum_{j=i}^{n} V_{j i}}{n}
$$

$\mathrm{Ki}_{\mathrm{i}}=$ Average of the criteria to $-\mathrm{i}$

$\mathrm{V}_{\mathrm{ji}}=\mathrm{jth}$ validator assessment score against the ith criterion $\mathrm{n}=$ Number of validators

The results obtained are written in the average column on the analysis sheet is the validation of the learning module. Finding the average aspect with the formula according to Khabib ah (2006) in Wicaksono (2014)

$$
A_{i}=\frac{\sum_{j=i}^{n} K_{j i}}{n}
$$

Information :

$\mathrm{A}_{\mathrm{i}}=$ Average aspect of $-\mathrm{i}$

$\mathrm{K}_{\mathrm{ij}}=$ Average for the $\mathrm{i}$-th aspect of the $\mathrm{j}$ criteria

$\mathrm{n}=$ Number of criteria in the $\mathrm{i}$-th aspect

The results obtained are written on the average of each aspect. Finding the average total validity of each aspect of the media with the formula according to Khabibah (200 6) in Wicaksono (2014)

$$
V a_{\text {media }}=\frac{\sum_{i=l}^{n} A_{i}}{n}
$$

$\mathrm{Va}_{\text {media }}=$ Average total validity of media

$\mathrm{A}_{\mathrm{i}}=$ Average aspect $-\mathrm{i}$

$\mathrm{n}=$ Number of criteria in the $\mathrm{i}$-th aspect

Average total with media validity criteria modified by $\mathrm{K}$ Habibah (2006) in Wicaksono (2014) are shown in Table 1.
TABLE 1

\begin{tabular}{ll}
\multicolumn{2}{c}{ TABLE 1 } \\
\multicolumn{1}{c}{ CRITERION VALIDITY LEARNING MEDIA } \\
\hline Score & Validity Criteria \\
\hline $3<$ Va medium 4 & Valid \\
$2<$ Va medium 3 & Quite Valid \\
$1<$ Va medium 2 & Invalid \\
\hline
\end{tabular}

Revise media until it is valid. The analysis was conducted after the participants fill out a questionnaire responses of participants. The activities carried out to fill in the student response data are Counting the number of students who choose SS, S, TS, STS on each question item \& Calculate the total score of each item for positive and negative statements. The scores for the questionnaire can be seen in Table 2.

TABLE 2

QUESTIONNAIRE SCORE

\begin{tabular}{llllll}
\hline \multirow{2}{*}{ No } & Statement & \multicolumn{4}{l}{ Answer } \\
\cline { 3 - 6 } & & SS & S & TS & STS \\
\hline 1 & Positive & 4 & 3 & 2 & 1 \\
2 & Negative & 1 & 2 & 3 & 4 \\
\hline
\end{tabular}

Calculate the average of each student's response for each statement with the formula according to Khabibah (2006) in Wicaksono (2014)

$$
R S_{\text {media }}=\frac{\sum P_{j s}}{n}
$$

RSmedia $=$ Average number of responses per student for each question after using the learning module

$\sum \mathrm{P}$ js = Point of choice of student answers for each question item $\mathrm{n}=$ The number of participants in the student .

Calculating the average percentage of students' response scores for each statement according to Khabibah (2006) in Wicaksono (2014)

$$
\% R S_{\text {media }}=\frac{R S_{\text {media }}}{4} \times 100 \%
$$

$\%$ RSmedia $=$ Percentage of the average number of response scores of each student for each question after using the learning module

Calculate the average number of student responses to all questions given.

Calculate the percentage of the average number of student responses to all the questions given .

Matching the average percentage of the number of student responses with the criteria according to Khabibah (2006) in Wicaksono (2014) which can be seen in Table 3.

TABLE 3

CRITERIA FOR RESPONSE TO LEARNING MEDIA

\begin{tabular}{lc}
\hline Score & Response Criteria \\
\hline $85 \%$ Rs medium & Very Positive \\
$70 \%$ Rs media $85 \%$ & Positive \\
$50 \%$ Rs media $70 \%$ & Less Positive \\
Rs media $50 \%$ & Not Positive \\
\hline
\end{tabular}




\section{RESULT AND DISCUSSION}

Assessment by media experts on e-learning modules conducted on: (1) Tech, (2) Aspects of language / communication, (3) Image and video, (4) Color, and (5) The layout is shown in Figure 1.

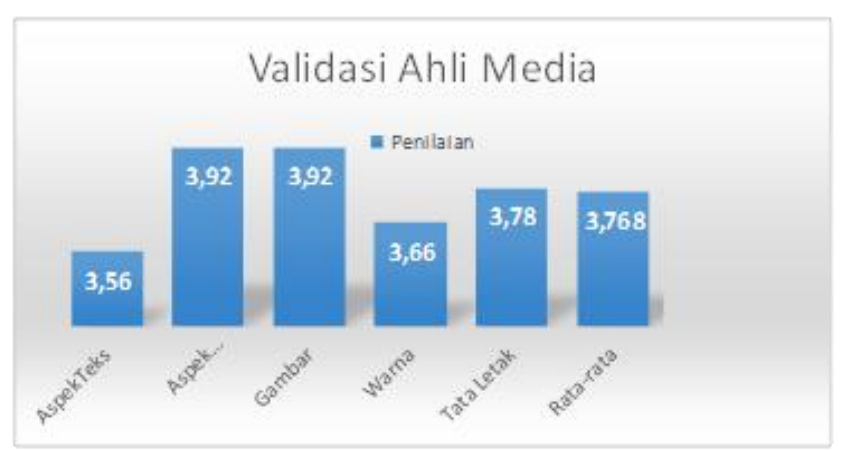

Figure 1 Data validation of learning media by media experts

Based on the data from the validation results of media experts, it shows that the learning e-module has an average value of 3.77 or greater than 3 . Referring to the validity criteria according to Khabibah, this learning e-module is valid in terms of text, language /communication aspects, pictures and videos, colors and layouts.

\section{Material Expert Assessment Results}

The assessment by the material expert on the learning emodule is carried out on: (1) Characteristics of the learning model (2) Design of learning activities (3) Stages of the learning model (4) Assumptions of design implementation (5) Assessment and learning strategies carried out. The results of the material expert's assessment of the learning e-module can be seen in Figure 2.

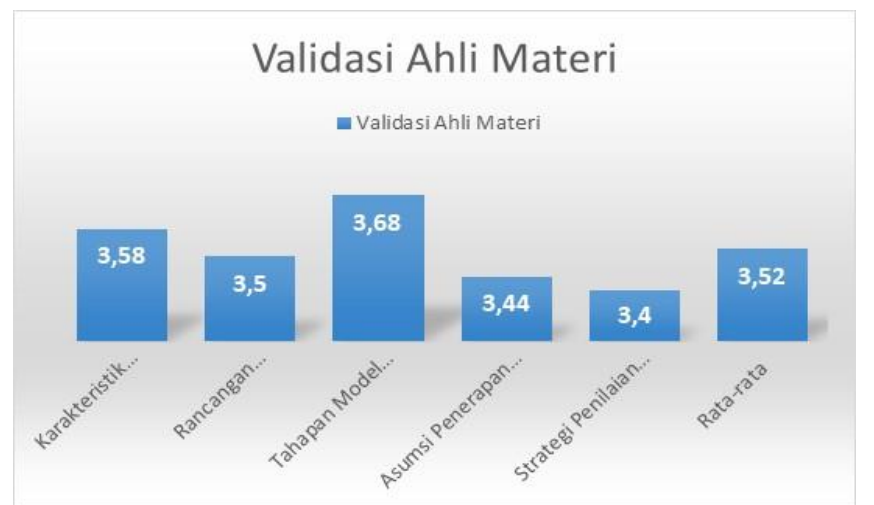

Figure 2 Data validation of teaching learning media by material experts

Figure 2 shows the learning module has an average value of 3.52 or greater than 3 . Referring to the validity criteria according to Khabibah, this e-learning module is valid from the aspects of the characteristics of the learning model, the design of learning activities, the stages of the learning model, the assumptions of the implementation of the design, the strategy assessment and learning carried out.

\section{Expert/Validator Assessment}

Through the results of activities at the e-module development stage that have been carried out previously, which includes an assessment of the feasibility of the emodule content being developed, the profile of the English learning module is described as shown in Table 4 and Table 5 .

TABLE 4.

CALCULATION OF E-MODULE VALIDATION RESULTS ON THE MEDIA ASPECT

\begin{tabular}{|c|c|c|c|c|}
\hline No & Aspect & No & Indicator & $\mathbf{A} \mathbf{i}$ \\
\hline \multirow[t]{9}{*}{ A } & Text & 1 & $\begin{array}{l}\text { The suitability of the text selection } \\
\text { on the e-module cover }\end{array}$ & 3.4 \\
\hline & & 2 & $\begin{array}{l}\text { The suitability of the content of the } \\
\text { text with the learning objectives. }\end{array}$ & 4 \\
\hline & & 3 & Use of the font on the cover & 3.6 \\
\hline & & 4 & Use of font in text content & 3.6 \\
\hline & & 5 & Use of font size & 3.6 \\
\hline & & 6 & Line usage accuracy & 3.8 \\
\hline & & 7 & The correct use of spaces & 3.6 \\
\hline & & 8 & Easy to read and understand text & 3.8 \\
\hline & & 9 & $\begin{array}{l}\text { Systematic a writing, materials, } \\
\text { summaries and exercises. }\end{array}$ & 3.4 \\
\hline \multirow[t]{3}{*}{ B } & Language & 1 & Clear instructions for use & 4 \\
\hline & aspect & 2 & $\begin{array}{l}\text { The suitability of language with } \\
\text { students' thinking level }\end{array}$ & 3.8 \\
\hline & & 3 & Impression of the use of language & 4 \\
\hline \multirow[t]{8}{*}{$\mathrm{C}$} & $\begin{array}{l}\text { Pictures } \\
\text { and }\end{array}$ & 1 & $\begin{array}{l}\text { Selection of images and videos } \\
\text { according to the material }\end{array}$ & 4 \\
\hline & videos & 2 & $\begin{array}{l}\text { Selection of real pictures and videos } \\
\text { not animation }\end{array}$ & 4 \\
\hline & & 3 & $\begin{array}{l}\text { Clarity of the form of images and } \\
\text { videos }\end{array}$ & 4 \\
\hline & & 4 & $\begin{array}{l}\text { The accuracy of the voter a } n \text { the } \\
\text { form of images and video are } \\
\text { consistent }\end{array}$ & 3.8 \\
\hline & & 5 & $\begin{array}{l}\text { The accuracy of the shape of } \\
\text { images, videos with text }\end{array}$ & 3.8 \\
\hline & & 6 & $\begin{array}{l}\text { Consistent selection of frames in } \\
\text { every image and video }\end{array}$ & 4 \\
\hline & & 7 & Display design image on cover & 4 \\
\hline & & 8 & $\begin{array}{l}\text { Continuity of images and videos in } \\
\text { the material as a whole }\end{array}$ & 4 \\
\hline \multirow[t]{6}{*}{$\mathrm{D}$} & Color & 1 & $\begin{array}{l}\text { E-module application color selection } \\
\text { accuracy }\end{array}$ & 3.8 \\
\hline & & 2 & $\begin{array}{l}\text { Clarity of color in the shape of the } \\
\text { image }\end{array}$ & 3.4 \\
\hline & & 3 & Clarity of color in the picture & 3.6 \\
\hline & & 4 & Color accuracy on the background & 3.8 \\
\hline & & 5 & Attractive color composition & 3.8 \\
\hline & & 6 & $\begin{array}{l}\text { Image color composition and image } \\
\text { caption text }\end{array}$ & 3.8 \\
\hline \multirow[t]{4}{*}{$\mathrm{E}$} & Layout & 1 & $\begin{array}{l}\text { Symmetrical image position with } \\
\text { text }\end{array}$ & 3.8 \\
\hline & & 2 & $\begin{array}{l}\text { The position of the image is } \\
\text { equipped with a frame }\end{array}$ & 3,6 \\
\hline & & 3 & Continuity between image and text & 4 \\
\hline & Va media & & & 3.77 \\
\hline
\end{tabular}

$\mathrm{Ai}=$ Average validation value of each aspect

Vamaterial $=$ Average total validation 
TABLE 5

CALCULATION OF MODULE VALIDATION RESULTS ON MATERIAL ASPECTS

\begin{tabular}{|c|c|c|c|c|}
\hline No & Aspect & No & Indicator & $\mathbf{A} \mathbf{i}$ \\
\hline \multirow[t]{9}{*}{ A } & \multirow[t]{9}{*}{$\begin{array}{l}\text { Learning } \\
\text { Model }\end{array}$} & 1 & $\begin{array}{l}\text { The suitability of learning and } \\
\text { learning theory that underlies } \\
\text { the design of the learning } \\
\text { model }\end{array}$ & 3.6 \\
\hline & & 2 & Have learning goals & 4 \\
\hline & & 3 & $\begin{array}{l}\text { Can be used as a guide for } \\
\text { improving learning activities } \\
\text { in the classroom and outside } \\
\text { the classroom }\end{array}$ & 3.4 \\
\hline & & 4 & $\begin{array}{l}\text { Has parts of the model in } \\
\text { implementation, namely the } \\
\text { sequence of learning steps } \\
\text { (syntax), principles, social } \\
\text { systems and support systems. }\end{array}$ & 3.6 \\
\hline & & 5 & $\begin{array}{l}\text { Has an impact as a result of } \\
\text { applying the learning model }\end{array}$ & 3.4 \\
\hline & & 6 & $\begin{array}{l}\text { There is preparation for } \\
\text { teaching learning }\end{array}$ & 4 \\
\hline & & 7 & $\begin{array}{l}\text { Have a specific level of } \\
\text { behavior }\end{array}$ & 3.4 \\
\hline & & 8 & $\begin{array}{l}\text { Have a specific learning } \\
\text { environment }\end{array}$ & 3.6 \\
\hline & & 9 & $\begin{array}{l}\text { Applying the evaluation of } \\
\text { learning outcomes }\end{array}$ & 3.6 \\
\hline \multirow[t]{3}{*}{ B } & \multirow[t]{3}{*}{$\begin{array}{l}\text { Learning } \\
\text { Activity } \\
\text { Design }\end{array}$} & 1 & $\begin{array}{l}\text { Conformity of the core } \\
\text { activity design with the } \\
\text { standard of the learning } \\
\text { implementation process }\end{array}$ & 3.4 \\
\hline & & 2 & $\begin{array}{l}\text { Conformity of the core } \\
\text { activity design with the } \\
\text { standard of the learning } \\
\text { implementation process }\end{array}$ & 3.8 \\
\hline & & 3 & $\begin{array}{l}\text { The suitability of the closing } \\
\text { activity design with the } \\
\text { standard of the learning } \\
\text { implementation process }\end{array}$ & 3.4 \\
\hline \multirow[t]{5}{*}{$\mathrm{C}$} & \multirow[t]{5}{*}{$\begin{array}{l}\text { Learning } \\
\text { Model Stages }\end{array}$} & 1 & $\begin{array}{l}\text { Systematics of learning } \\
\text { models }\end{array}$ & 3.6 \\
\hline & & 2 & $\begin{array}{l}\text { The learning model is easy for } \\
\text { students to follow }\end{array}$ & 3.6 \\
\hline & & 3 & $\begin{array}{l}\text { The learning model is easy to } \\
\text { follow by lecturers / teachers }\end{array}$ & 3.8 \\
\hline & & 4 & $\begin{array}{l}\text { The relationship between the } \\
\text { activity stages and the } \\
\text { learning objectives }\end{array}$ & 3.6 \\
\hline & & 5 & $\begin{array}{l}\text { The continuity of each stage } \\
\text { of learning activities from the } \\
\text { initial, core and closing } \\
\text { activities }\end{array}$ & 3.8 \\
\hline \multirow[t]{3}{*}{$\mathrm{D}$} & \multirow[t]{3}{*}{$\begin{array}{l}\text { Assumptions } \\
\text { Implementation } \\
\text { of the design }\end{array}$} & 1 & $\begin{array}{l}\text { Practicality of the model (can } \\
\text { be developed and applied) }\end{array}$ & 3.6 \\
\hline & & 2 & $\begin{array}{l}\text { Effective } \\
\text { implementation }\end{array}$ & 3.4 \\
\hline & & 3 & $\begin{array}{l}\text { The application of the } \\
\text { learning model will give } \\
\text { results in accordance with the } \\
\text { objectives }\end{array}$ & 3.6 \\
\hline \multirow[t]{4}{*}{$\mathrm{E}$} & \multirow{3}{*}{$\begin{array}{l}\text { Assessment } \\
\text { and Learning } \\
\text { Strategies } \\
\text { carried out }\end{array}$} & 1 & Relationship aspects of & 3.4 \\
\hline & & & $\begin{array}{l}\text { learning assessment with } \\
\text { learning objectives }\end{array}$ & \\
\hline & & 2 & $\begin{array}{l}\text { Assessment of the scope of } \\
\text { theoretical and practical } \\
\text { material }\end{array}$ & 3.4 \\
\hline & Va material & & & 3.52 \\
\hline
\end{tabular}

A $\mathrm{i}=$ Average validation value of each aspect

Va material $=$ stocking of average total validation

\section{Student Response after Using E-Module}

Some of the findings related to the responses of students in this study are:

During learning activities using e-modules, students give a good response, which is indicated by the activeness of students in learning and understanding the modules provided. Students are also active in asking questions related to the content of the e-module.

Students dare to convey the ideas and understandings that have been obtained after studying the descriptive text material by presenting the contents of the material in front of the class and are willing to accept input from other students regarding the shortcomings or misconceptions of the concepts that have been studied.

Students' understanding of the descriptive text material is quite good, which is indicated by the results of measuring the level of understanding of students using test questions. The measurement of the level of understanding of students is carried out using a pretest and posttest which will be held on 26 and 29 April 2021.

The measurement of the level of understanding was carried out on students of class X MIPA MAN 3 Pontianak with a total of 21 students. The results of the pre test and post test can be seen in Table 6 .

TABLE 6

LEARNING OUTCOMES

\begin{tabular}{llll}
\multicolumn{4}{c}{ LEARNING OUTCOMES } \\
\hline Subject Trial & Pre test & Post test & Difference \\
\hline Total Value & 910 & 1.660 & 750 \\
Average & 43.33 & 79.04 & 35.71 \\
\hline
\end{tabular}

Based on Table 6, it shows that there are differences in the average learning outcomes of small group test subjects before and after learning using the module. Before learning the average value of student learning outcomes is 43.33 while after learning is 79.04 with a difference of 35.71 .

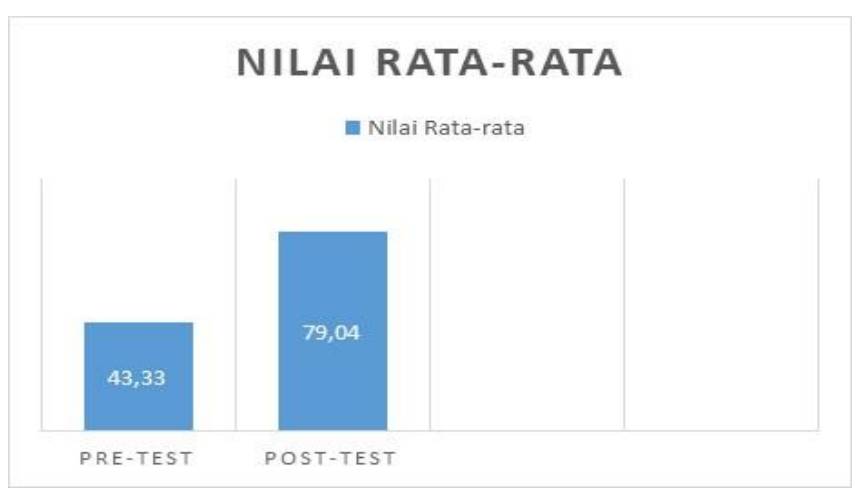

Figure 3 . Comparison chart of learning outcomes

Figure 3 shows that the use of e-modules can improve students' understanding of descriptive text material. The difference in learning outcomes before and after learning 
using learning modules shows that e-learning modules can help students understand descriptive text material.

\section{Design and Development Stage of E-Learning Module}

The development design includes a preliminary study carried out by forming a framework for making learning emodules. Through this study, researchers collect information related to things needed in preparing writing plans and developing learning modules. The findings of the e-learning module development design in this study are:

Analysis of curriculum and learning resources (Front and analysis). The findings show that the curriculum used at MAN 3 Pontianak is the 2013 curriculum, namely the curriculum with a scientific approach. Kur ikulum supporting learners to learn iuris with an emphasis on $p$ engalaman learners when learning. However, in reality it is not supported by adequate learning resources such as the limitations of textbooks and learning media used by educators and the Covid-19 pandemic condition which ultimately uses the Covid-19 emergency curriculum.

Analysis of student characteristics (Learner analysis). The findings show that the ability of students to understand the concept of English material is still low, learning motivation is not good, new learning experiences with English material, the tendency to learn independently and interest in learning through learning resources that are in accordance with the characteristics and learning styles. each of them.

Task Analysis. The findings show that the learning task of students is to study descriptive text material. However, the findings did not explain whether the learning task was carried out independently or not. So that in this study, the task of learning students to study descriptive texts was formulated in independent learning activities using designed teaching materials. Conceptual knowledge that has been possessed by students through the learning assignments is discussed in groups. Through the delivery of ideas in front of the class (feedback) students are invited to prove the truth of the concepts they have learned.

Analysis of the concepts taught (Concept Analysis). The findings show that the descriptive text material studied in class X consists of several important concepts, namely: (1) Definition of descriptive text, (2) Purpose of descriptive text, (3) Language features or language features, (3) Generic structures or structures. general text, and (5) Tenses related to the material.

So that the delivery of this material is carried out in a coherent manner because the characteristics of the material are a combination of the concepts of knowledge and skills and are interrelated between one concept and another.

Formulating learning objectives (Spefying instructional objectives). So that students can understand the material of descriptive text, in this study, the learning objectives that must be achieved by students are formulated.

Students are accustomed to being grateful for the ability to control themselves in every learning activity, always working together and being caring in doing group assignments inside and outside the classroom, distinguishing
(1) social functions, (2) text structure and (3) linguistic elements of the text. Descriptive; Famous Tourist Attractions and Historic Buildings clearly and precisely when asked a question, and can interpret the contents of descriptive text appropriately and smoothly inside and outside the classroom.

\section{Trial Using E-Module}

This e-module readability test activity was carried out through 3 stages, namely individual trials, small group trials, and large group trials, on several students in class X MIPA by providing response questionnaires which would later be used as input in revise the product.

1) Test Cob A Individual : in the implementation of this trial are expected researchers can study the response $d$ 's comment on the subject of the trial on the design of modules that have been designed. In addition, from this trial, researchers are expected to be able to see the shortcomings contained in the learning module as a reference in revising the module that is being developed. The findings during the individual trial are as follows:

- The trial was carried out on April 21, 2021 at 07.30 - 09.30 wib at MAN 3 Pontianak

- The trial subjects consisted of 3 students in class XM IPA 2. The selection of the trial subjects was carried out randomly, consisting of 1 student with high ability, 1 student with moderate ability, 1 student with low ability.

- The results of student responses after learning using e-modules are described that the results of students' positive responses to e-learning modules are $78.48 \%$, these results indicate that descriptive text learning e-modules can be used and are interesting for students in learning English. gris in class.

2) Small Group Trial : In this trial, in addition to obtaining student responses to the learning e-module, the researcher also conducted a trial of learning scenarios. This is done so that learning activities using e-modules that are designed can be applied in the classroom using the stages of learning that have been prepared previously. The findings in the small group trial are as follows:

- $\quad$ The trial will be held on April 23, 2021 at 07.30 09.30 wib at MAN 3 Pontianak

- The test subjects were 6 students of class X MIPA. Selection of subjects randomized trials consisting of 2 pesert a learner capable top, 2 people learners capable of being, 2 participants didi k low ability.

- The results of observations when implementing learning in the classroom show that e-learning modules can be used as teaching materials in learning activities using a learner-oriented approach.

- During learning activities, the use of e-modules can help students understand the concepts being studied.

- The results of student responses after the implementation of learning using e-modules are $79.45 \%$, the results of this calculation show that de scriptive text learning e-modules can be used and 
are interesting for students in learning English in the classroom.

3) Large Group Trial: The third trial phase carried out in the development stage of the "learning descriptive text" emodule is a large group trial. The purpose of implementing the large group trial is to find out the response of students to e-learning modules as well as to test the effectiveness of using e-modules on learning activities and students' abilities. The findings during the large group trial are as follows:

- The trial will be held on 26 and 27 April 2021 at 07.30 - 09.30 wib at MAN 3 Pontianak with details of the following activities:

TABLE 7

SCHEDULE OF LARGE GROUP TRIAL ACTIVITIES

\begin{tabular}{llllll}
\hline $\begin{array}{l}\text { Date } \\
\text { time }\end{array}$ & and & Execution time & Activity \\
\hline 26 & April & $\begin{array}{l}07.30 \\
\text { wib }\end{array}$ & -07.45 & $\begin{array}{l}\text { Prepare e-modules and } \\
\text { learning scenarios that } \\
\text { will be used in learning } \\
\text { activities. }\end{array}$ \\
\hline 26 & April & 07.45 & -09.00 & $\begin{array}{l}\text { Carry out learning } \\
\text { activities for the } \\
\text { "learning descriptive } \\
\text { text" module using the } \\
\text { stages of constructivist } \\
\text { learning }\end{array}$ \\
& & am & & & $\begin{array}{l}\text { Provide response } \\
\text { questionnaires } \\
\text { students related to the } \\
\text { use of e-modules in } \\
\text { learning activities. }\end{array}$ \\
\hline & April & 07.30 & -08.00 & &
\end{tabular}

- The subjects of the large group trial were students of class X MIPA with a total of 21 students.

- The implementation of learning activities during the large group trial was carried out with reference to the improvement results from the learning scenario during the small group trial . With this, it is expected that during the application of e-module learning using the learning stages using a constructivist approach can be done well.

- The results of the large group trial after learning using the module are $83.15 \%$, the results of this calculation according to Khabibah show that the learning descriptive text learning module can be used and is interesting for students in learning English in the classroom.

\section{E-Module Profile}

The product profiles contained in the high school English learning e-module are as follows:

- The module developed is in the form of an Electronic Module with the theme "Learning Descriptive Text"

- The module contains descriptive text material consisting of understanding descriptive text, descriptive text objectives, language features, generic structures, related tenses and examples of relevant material.
- The module has the characteristics of Self Instruction, Self Contained, Stand Alone, Adaptive, and Friendly (User Friendly)

- Module 1 is presented in electronic form. This module is divided into four buttons which contain menu, profile, help and exit buttons.

In the menu there are 3 sections, namely:

1) Module : contains instructions, $\mathrm{KI} / \mathrm{KD}$ and indicators, concept maps and the contents of the module. P No button $\mathrm{KI} / \mathrm{KD}$ and indicators contain about KI / KD indicators according syllabus and lesson plans taught. The content section of the module contains learning materials, practice essays, assessments, glossaries and bibliography.

2) Video section : contains video warming up related to the material being taught.

3) Practice section : contains pre-test and post-test .

The appearance of the e-module profile is as follows:
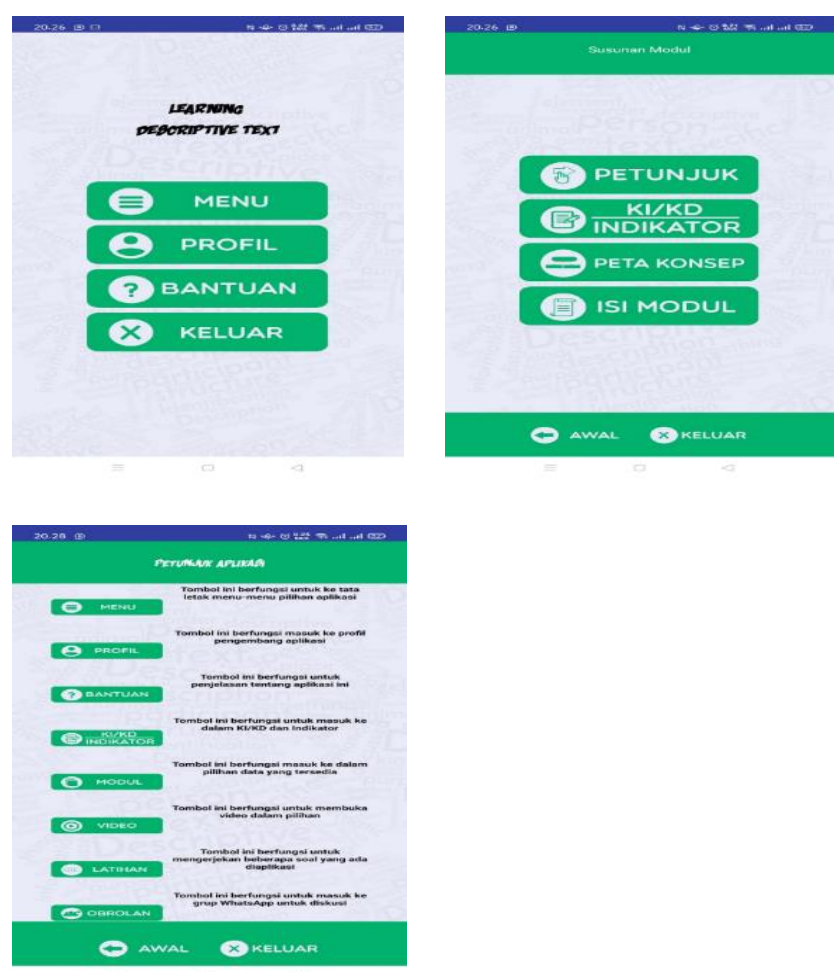

Figure 4. e-module profile display on a mobile phone.

\section{Student Response after Using E-Module}

The results of student responses after the implementation of learning using e-modules show that the descriptive text learning e-module can be used and is interesting for students in learning English in the classroom. This is indicated by the number of people who gave a positive response to the emodule. The use of descriptive text learning e-modules is basically intended to help students face learning difficulties in mastering the material. Students do not hesitate to ask questions related to the content of the e-module. In addition, students boldly convey the ideas/understandings that they have obtained after studying the concept of descriptive text by presenting the material in front of the class and are 
willing to accept input from other students regarding the shortcomings or misunderstandings that have been learned.

The test results given to students showed that there were differences in student learning outcomes before and after using the e-learning module. E-learning modules in research are basically used as substitutes for textbooks or textbooks which students do not have, this module is made in the easiest language possible so that e-modules can support students in building their own concepts or commonly known as constructivism theory so that Mastery of the concept of students will be more mastered because students themselves find the concept and build it.

Understanding in learning English is more meaningful if it is built by the students themselves. Therefore, the ability pemahama $\mathrm{n}$ can not be given by force, meaning matericourses were taught by educators, and when learners forget that learners are not able to properly settle the issue kuhusunya in learning English. The e-module in this study had a positive impact as evidenced by the activities of students in the classroom, when asked randomly and when asked questions by the teacher, students were able to explain about descriptive text material.

In addition to increasing understanding which increases students ' positive responses to learning using e-learning modules, it shows that the preparation of learning e-modules has been in accordance with the characteristics of students. E-modules can effectively help motivate students in learning because they are familiar with students. The module also meets the rules user- friendly in pe makaiannya. Every instruction and information display that appears is helpful and friendly to its use, including the ease with which the user can respond and access it as desired. The use of language that is simple, easy to understand, and uses commonly used terms, is a form of user-friendliness.

\section{CONCLUSION}

The design and development stages of the learning emodule in this study are a complete series of activities and become a reference in the e-module development process. The design of e-module development in this study can be grouped in detail into 3 parts, namely (1) Analysis of curriculum content and selection of materials used as the basis for selecting learning materials and resources. Researchers conducted a conformity analysis on competencies in the curriculum that was being used, namely the revised 2013 curriculum; (2) Analysis of the characteristics of students as the initial goal of developing the resulting product as well as being a reference in designing e-modules. The results of the analysis by researchers show that the designed e-learning module must have simple characteristics starting from the language and content of the material; (3) Analysis of students' learning assignments in this case becomes the basis for formulating learning objectives and becomes a benchmark for the success of using e-modules.

The formulation of learning objectives carried out by researchers includes two aspects, namely the formulation of cognitive and affective learning objectives . The stages of developing learning e-modules with a constructivist approach are carried out through (1) Designing learning emodules based on the learning objectives that have been formulated. The writing of the contents of the e-module begins with the activity of collecting material from class $\mathrm{X}$ English textbooks and other sources from the internet by researchers; (2) Validating the feasibility of the contents of the e-module by experts in their field to obtain a feasibility score and suggestions for improvement of the e-module design, validation is carried out by direct researchers face to face with experts ; (3) Conducting field trials to class $\mathrm{X}$ students of MAN 3 Pontianak to obtain responses and effectiveness of e-learning modules.

The profile of the English learning e-module in this study has met the characteristics of Self Instruction, Self Contained, Stand Alone, Adaptive, and User Friendly. The module is presented in electronic form. The module contains descriptive text material, where the learning activities are divided into 6 learning activities, equipped with supporting pictures and text and equipped with exercises that can make students active in using e-modules. This e-module is very interactive. This e-module is divided into four buttons which contain menu, profile, help and exit buttons. In the menu section there are 3 sections, namely: Menu Options, Profiles, and Help.

The feasibility of this e-module has been tested through the assessment of media and material experts as well as through field trials on students as users of the learning emodule.

The response of the students in this study was the response in the aspect of attitudes and interests, namely the use of descriptive e-text learning modules which were basically intended to help students in dealing with learning difficulties in mastering the material. Students do not hesitate to ask questions related to the content of the module. In addition, students bravely convey the ideas /understandings that they have gained after studying the concept of descriptive text material by presenting the material in front of the class and are willing to accept input from other students regarding the shortcomings or misunderstandings that have been learned. Furthermore, students are able to understand descriptive text material in order to solve learning problems experienced including completing questions and test questions given during learning activities. And the average cognitive learning outcomes of students before using the e-module $=43.33$ and after using the e-module $=79.04$ (range 1-100) .

\section{REFERENCES}

Astuti, Indri. (2020). Desain Pembelajaran Dalam Perspektif Kontruktivistik. Pontianak: IAIN Pontianak Press.

Daryanto. (2013). Menyusun Modul (Bahan Ajar Untuk Persiapan Guru Mengajar). Yogyakarta: Penerbit Gava Media.

Gufron, M. Nur \& Risnawita, Rini. (2014). Gaya Belajar Kajian Teoretik. Yogyakarta: Pustaka Belajar. 
Khabibah, Siti. (2006). Pengembangan Model pembelajaran Matematika dengan soal Terbuka untuk meningkatkan Kreatifitas peserta didik sekolah dasar. Disertasi. Tidak dipublikasikan. Surabaya: Program Pasca Sarjana Universitas Negeri Surabaya.

Sanaky, Hujair. (2011). Media Pembelajaran. Yogyakarta: Kaukaba Dipantara.

Sugiyono. (2017). Memahami Penelitian Kualitatif. Bandung: Alfabeta.

Sukardi., \& Sutapa, Y. G. (2015). Model Konstruktivistik Membangun Konsep Pembelajaran Bahasa Inggris Kelas VII SMP Negeri 4 Siantan. Jurnal Pendidikan dan Pembelajaran Khatulistiwa, 4(11).

Wicaksono, D. P., Kusmayadi, T. A., \& Usodo, B. (2014). Pengembangan perangkat pembelajaran matematika berbahasa inggris berdasarkan teori kecerdasan majemuk (multiple intelligences) pada materi balok dan kubus untuk kelas VIII SMP. Jurnal Pembelajaran Matematika, 2(5). 